\title{
Related Fisheries Management of Fish and Phytoplankton Biodiversity with Relationship to Primary Productivity of the Govardhan Sagar Lake, Udaipur, Rajasthan
}

\author{
Bhatt Nakul A. ${ }^{{ }^{*} \#, \text { T. Kumawat }}{ }^{2}$, E. Singh ${ }^{3}$ and A. Priyadarshini ${ }^{3}$ \\ ${ }^{1}$ College of Fisheries, MPUAT, Udaipur, Rajasthan (313 001), India \\ \#Presently Regional Centre of ICAR-CMFRI, Veraval, Gujarat (362 269), India \\ ${ }^{2}$ Regional Centre of ICAR-CMFRI, Veraval, Gujarat (362 269), India \\ ${ }^{3}$ College of Agriculture Science and Technology, Selaqui, Dehradun, Uttarakhand (248 001), India
}

\author{
Corresponding Author \\ Bhatt Nakul A. \\ e-mail: nakulbhatt66@gmail.com
}

\author{
Article History \\ Article ID: AR1942 \\ Received in $15^{\text {th }}$ December, 2018 \\ Received in revised form $13^{\text {th }}$ January, 2019 \\ Accepted in final form $07^{\text {th }}$ February, 2019
}

\begin{abstract}
The present study on the related fisheries management of fish and phytoplankton biodiversity with relationship to primary productivity of the Goverdhan sagar Lake was conducted during October 2017 to September 2018. The Lake has a fairly rich fish fauna and so far, 18 species representing 6 families have been recorded in the present investigation, of these, 9 species predominantly contributed to the commercial fisheries of the Lake. In the present study, water quality parameters such as transparency, $\mathrm{pH}$, alkalinity, free carbon dioxide, air and water temperature, dissolved oxygen, primary productivity, conductivity, nitrate-nitrogen, and orthophosphate were done along with qualitative and quantitative estimation of phytoplankton. The study indicated that the average primary productivity (GPP) of the Goverdhan sagar Lake was found to be $0.70 \mathrm{~g} \mathrm{~cm}^{3} \mathrm{~h}^{-1}$, NPP $\left(0.57 \mathrm{~g} \mathrm{~cm}^{3} \mathrm{~h}^{-1}\right)$ and CR was found to be $0.27 \mathrm{~g} \mathrm{~cm}^{3} \mathrm{~h}^{-1}$ in the surface. Algae in fresh water have numerous environmental functions and are based upon the recycling of nutrients. Totally 36 species of phytoplankton belonging to different taxonomic group were identified. Among these 09 species to belong to Bacillariophyceae, 12 species to chlorophyceae, 12 species to cyanophyceae and 03 speceis to desmidiaceae. The Indian major carps were dominated the catch by contributing $85 \%$ of the total landings from the Lake whereas minor carps and catfishes were reported as $8.5 \%$ and $6.5 \%$ respectively.
\end{abstract}

Keywords: Goverdhan sagar lake, phytoplankton diversity, primary productivity

\section{Introduction}

India is one of the mega biodiversity countries in the world and occupies ninth position in terms of freshwater mega biodiversity. In India, there are 2,500 species of fishes; of which, 930 live in freshwater and 1570 are marine (Kumar and Patra, 2013). Out of these, 400 species are commercially important which includes wild and culturable species (Das, 1994). The aquatic ecosystems have been subjected to various forms of environmental stress, during the past few decades. Most of such environmental problems are man-made and thus increased human activities in the catchment area of various aquatic systems have affected the natural processes of these systems adversely thereby threatening the survival and growth of biotic communities (Khanna et al., 2012).

Rajasthan is also endowed with varied surface freshwater resources like reservoirs, seasonal and a couple of perennial rivers, canals, small tanks and ponds. In an earlier estimate, Rajasthan was having around 4.23 lakh ha of water area. Out of this, large and medium reservoirs constitute about 02.5 mha of water area, small reservoirs and ponds contribute 1.76 lakh ha, whereas, 0.30 lakh ha water area is available in the form of rivers and canals (Bhatt et al., 2016). Goverdhan Sagar is a shallow Lake with a Catchment area of $2.56 \mathrm{sq} . \mathrm{km}$, maximum depth $(\mathrm{Zm})$ of $7.62 \mathrm{~m}$, maximum length $(\mathrm{L}) 1.97 \mathrm{~km}$, maximum width (bx) $0.72 \mathrm{~km}$ and a shoreline of 3888.8 meters with relatively fringed margins and an area of 30.81 ha. The Lake is totally rain-fed and retains water throughout the year. The over-flooded Pichhola Lake and Kotra river feeds water to the Goverdhan Sagar. (Mishra et al., 2016).

Phytoplanktons are the main primary producers in water bodies and influence structure and density of consumers and characteristics of water. Moreover, phytoplanktonic organisms are sensitive indicators, as phytoplankton structure and metabolism change quickly in response to environmental changes (Mishra et al., 2012). Growth rate and variability of phytoplankton are subject to cyclic changes of fluctuation and succession. Phytoplanktons constitute a major part of aquatic vegetation, they being primary producers which support the growth of aquatic fauna and produce oxygen by 
the photosynthetic process (Chinnaiah et al., 2010). Biological features such as temperature, transparency, $\mathrm{pH}$, alkalinity, free carbon dioxide, dissolved oxygen, electrical conductivity, nitrate-nitrogen, orthophosphate etc. of any water body grossly determine the trophic status of the water body. Such parameters influence the primary productivity and in turn the growth of the fish. The primary productivity of different water bodies has been widely investigated to assess the fish production potentialities of a water body to formulate appropriate fishery management policies (Friedland et al., 2012). Considering the local conditions in the account, an attempt was made to find out the fish and phytoplankton biodiversity with relationship to primary productivity of the Goverdhan sagar Lake, Udaipur.

\section{Materials and Methods}

\subsection{Sample collection}

In the present study, three sampling stations were selected in the Goverdhan sagar Lake for collection and analysis at weekly interval. Total 3 stations of selected for this work (Station A, $B$ and $C$ ). In order to study the biodiversity, samples of fishes were collected from the commercial catches and sample netting during the fishing year 2017-18 at landing center of the Goverdhan sagar Lake. As far as possible fishes were identified in the field itself using standard manuals (Day, 1994; Talwar and Jhingran, 1991). Species that could not be identified in the field were preserved in 4 percent formalin and brought to the laboratory for identification.

\subsection{Primary productivity}

Primary productivity was measured at all the three stations following light and dark bottles method. For this purpose, glass-stoppered black and white BOD bottles of $250 \mathrm{ml}$ were used. The bottles were suspended about $15 \mathrm{~cm}$ below the water line. The incubation period was three hours. Oxygen $\left(\mathrm{O}^{2}\right)$ estimations in the BOD bottles were made following usual Winkler's method (APHA, 2005). The calculation was done as under

Gross Oxygen Production (GOP) $\mathrm{mg} \mathrm{l}^{-1}=\mathrm{LB}-\mathrm{DB}$

Net Oxygen Production (NOP) $\mathrm{mg} \mathrm{|}^{-1}=\mathrm{LB}-\mathrm{IB}$

Community Respiration (CR) $\mathrm{mg} \mathrm{I}^{-1}=\mathrm{IB}-\mathrm{DB}$

The values of gross and net primary productivity were calculated as follows

Gross Primary Productivity $\left(\mathrm{g} \mathrm{cm}^{3} \mathrm{~h}^{-1}\right)=\mathrm{GOP} \times 0.375 / 1.2 \times \mathrm{h}$

Net Primary Productivity $\left(\mathrm{g} \mathrm{cm}^{3} \mathrm{~h}^{-1}\right)=\mathrm{NOP} \times 0.375 / 1.2 \times \mathrm{h}$

Where,

$\mathrm{LB}=$ Dissolved oxygen in light bottle

$\mathrm{DB}=$ Dissolved oxygen in dark bottle

$\mathrm{IB}=$ Dissolved oxygen in the initial bottle

$\mathrm{H}=$ Duration of incubation or exposure

1.2=A constant
$1.375=\mathrm{A}$ factor value ( $1 \mathrm{~g}$ of oxygen is equal to $0.375 \mathrm{~g}$ of carbon)

\subsection{Plankton analysis}

For these 50 liters of water was filtered through bolting silk no. 25 (mesh size $60 \mu \mathrm{m}$ ) and plankton thus obtained were preserved in Lugol's solution for further quantitative and qualitative analyses. The qualitative analysis of phytoplankton was done using standard procedure (Senthikumar and Sivakumar, 2008). The identification of phytoplankton was restricted only upto major groups viz., Cyanophycean, Chlorophyceae, Bacillariophyceae and Desmidiaceae.

\section{Results and Discussion}

\subsection{Fish diversity}

The fish faunal varieties found in the present investigation have been depicted in Table 1 . This table clearly indicates that total 18 fish species belonging to 6 families were found from the Goverdhan sagar Lake. Thus, the fish faunal structure appears fairly rich. Out of the recorded 18 fish species, only 11 species viz., Catla, Mrigala, Rohu, Kharpata, Sarsi, Puthi, Chal, Pabda, Lanchi, Singhi and Channa contributed to the

Table 1: List of fish fauna represented in the catch from the Goverdhan sagar Lake, Udaipur

\begin{tabular}{|c|c|c|c|}
\hline \multirow[t]{2}{*}{ No. } & \multirow[t]{2}{*}{ Family } & \multicolumn{2}{|l|}{ Species } \\
\hline & & Scientific name & Local name \\
\hline \multirow[t]{9}{*}{1.} & Cyprinidae & Catla catla (Ham.) & Catla \\
\hline & & Labeo rohita (Ham.) & Rohu \\
\hline & & Labeo calbasu (Ham.) & Kharpata \\
\hline & & Labeo gonius & Sarsi \\
\hline & & Cirrhinus mrigala (Ham.) & Mrigala \\
\hline & & Puntius sophore (Ham.) & Puthi \\
\hline & & Tor khudree & Mahseer \\
\hline & & Cirrhina reba & Reba \\
\hline & & Chela bacaila & Chal \\
\hline \multirow[t]{2}{*}{2.} & Channidae & Channa channa & Channa \\
\hline & & Channa puncatatus & Girhi \\
\hline 3. & $\begin{array}{l}\text { Notopteri- } \\
\text { dae }\end{array}$ & $\begin{array}{l}\text { Notopterus notopterus } \\
\text { (Pallas) }\end{array}$ & Patola \\
\hline 4. & $\begin{array}{l}\text { Mastacem- } \\
\text { belidae }\end{array}$ & Mastacembelus armatus & Bam \\
\hline \multirow[t]{3}{*}{5.} & Siluridae & Ompak pabda (Bloch) & Pabda \\
\hline & & Wallago attu (Bloch) & Lanchi \\
\hline & & $\begin{array}{l}\text { Heteropneustes fossilils } \\
\text { (Bloch) }\end{array}$ & Singhi \\
\hline \multirow[t]{2}{*}{6.} & Baridae & Mystus seenghala & Singhara \\
\hline & & Mystus aor & Pitar \\
\hline
\end{tabular}


commercial catch of this reservoir. Indian major carps have dominated the fishery of the Lake followed by the minor carps and catfishes.

In general, the Indian major carps appear to contribute around $85 \%$ to the total landings of the Goverdhan sagar Lake. While the percent contributions of minor carps and catfishes in the total catch were only $8.5 \%$ and $6.5 \%$, respectively. Amongst the Indian major carps, Catla catla dominated by (65.88\%) followed by Labeo rohita (15.29\%) and Cirrhinus mrigala (18.82\%).Further, in the case of minor carps, Labeo gonius dominated with a contribution of $76.47 \%$ followed by Puntius sophore(17.64\%). Other fish species formed $5.88 \%$ of the total minor carp catch. The catfishes have also made a smaller contribution to the landings of the Goverdhan sagar Lake, the highest catfish landing being of Wallago attu followed by Mystus seenghala, Ompak bimaculatus and Mastacembelus armatus were seen in Table 2. Datta and Majumdar (1970)

Table 2: Species composition of the total fish landing from the Goverdhan sagar Lake during study period 2017-18

\begin{tabular}{llcc}
\hline No. & Fish group & \multicolumn{2}{c}{ Composition (\%) } \\
\cline { 3 - 4 } & & In group & $\begin{array}{c}\text { In total fish } \\
\text { production }\end{array}$ \\
\hline 1. & Major Carps & 100.00 & 85.00 \\
& Catla catla (Ham.) & 65.88 & 56.00 \\
Labeo rohita (Ham.) & 15.29 & 13.00 \\
Cirrhinus mrigala (Ham.) & 18.82 & 16.00 \\
Minor carps & 100.00 & 8.50 \\
Labeo spp. & 76.47 & 6.50 \\
$\quad$ Puntius spp. & 17.64 & 1.50 \\
Miscellaneous & 5.88 & 0.50 \\
Cat Fishes & 100.00 & 6.50 \\
Wallago attu & 30.76 & 2.00 \\
Ompak pabda & 24.61 & 1.60 \\
Mastacembelus armatus & 12.30 & 0.80 \\
Mystus seenghala & 27.69 & 1.80 \\
Miscellaneous & 4.61 & 0.30 \\
\hline
\end{tabular}

made an extensive survey at 93 collection stations in 14 districts of Rajasthan from which fishes were obtained and reported 75 fish species. Other many researchers were notable contributions on the fish fauna of the Rajasthan are from (Bhatt et al., 2018; Khan and Pathan, 2016).

\subsection{Primary productivity}

The results pertaining to gross and net primary productivities of the Goverdhan sagar Lake during the study period (October 2017 to September 2018) are presented in Tables 3 to 5. In general, the GPP ranged between 0.30 to $0.60,0.30$ to 0.65 and 0.35 to $0.70 \mathrm{~g} \mathrm{C} \mathrm{m}^{3} \mathrm{~h}^{-1}$ at stations $\mathrm{A}, \mathrm{B}$ and $\mathrm{C}$, respectively. The average values of GPP were $0.40,0.42$ and $0.44 \mathrm{~g} \mathrm{~cm}^{3} \mathrm{~h}^{-1}$.

The statistical relationship of GPP was found positive with NPP, Community Respiration (CR) and total phytoplankton. The respective values of net primary productivity (NPP) at stations A, B and C ranged from 0.20-0.50, 0.25-0.55 and 0.25-0.45 g $\mathrm{cm}^{3} \mathrm{~h}^{-1}$. The average values of NPP were $0.36,0.40$ and $0.37 \mathrm{~g}$ $\mathrm{cm}^{3} \mathrm{~h}^{-1}$. The statistical relationship of NPP was found positive with GPP and total phytoplankton. The respective values of community respiration (CR) at stations $A, B$ and $C$ ranged from 0.05 to $0.20,0.10$ to 0.20 and 0.05 to $0.20 \mathrm{~g} \mathrm{~cm}^{3} \mathrm{~h}^{-1}$. The corresponding average values of $C R$ were $0.12,0.15$ and 0.13 $\mathrm{g} \mathrm{cm}^{3} \mathrm{~h}^{-1}$.The statistical correlation of CR was found positive GPP. However, there was a negative relationship with, NPP and total phytoplankton. All water quality parameters of the Goverdhan sagar Lake were shown in Table 6.

\subsection{Phytoplankton diversity}

The phytoplankters constitute the bulk of primary producers and are the base of food chains in any water body. The phytoplanktonic community of the Goverdhan sagar Lake during the present was represented by four major group's viz., Cyanophyceae, Chlorophyceae, Bacillariophyceae and Desmidiaceae. Overall 36 genera of algae were recorded in Goverdhan sagar Lake during the present study. Out of the total 36 genera, 12 were from Cyanophyceae, 9 from Bacillariophyceae, 12 from Chlorophyceae, and 3 belongs to Desmidiaceae.

However, Kumar et al. (2015) were found the phytoplanktonic community of water body was represented by six groups namely Chlorophyceae, Bacillariophyceae, Desmidiaceae, Xanthophyceae, Myxophyceae and Dinophyceae. Total 58 forms were identified and out of these 28 belonged to Chlorophyceae, 11 to Bacillariophyceae, 9 to Myxophyceae, 4 to Dinophyceae, 3 to Desmidiaceae and 3 to Xanthophyceae.

Table 3: Weekly observation of biological characteristics of surface water at station "A" of Goverdhan sagar Lake, Udaipur

\begin{tabular}{|c|c|c|c|c|c|c|c|c|c|c|c|c|c|c|c|c|c|c|}
\hline No. & Parameters & $\begin{array}{l}\text { I } \\
\text { (\%) }\end{array}$ & $\begin{array}{l}\text { II } \\
\text { (\%) }\end{array}$ & $\begin{array}{l}\text { III } \\
(\%)\end{array}$ & $\begin{array}{l}\text { IV } \\
\text { (\%) }\end{array}$ & $\begin{array}{l}\mathrm{V} \\
\text { (\%) }\end{array}$ & $\begin{array}{l}\text { VI } \\
\text { (\%) }\end{array}$ & $\begin{array}{l}\text { VII } \\
\text { (\%) }\end{array}$ & $\begin{array}{l}\text { VIII } \\
\text { (\%) }\end{array}$ & $\begin{array}{l}\text { IX } \\
(\%)\end{array}$ & $\begin{array}{l}X \\
\text { (\%) }\end{array}$ & $\begin{array}{l}X I \\
\text { (\%) }\end{array}$ & $\begin{array}{l}\text { XII } \\
\text { (\%) }\end{array}$ & $\begin{array}{l}\text { Avg. } \\
\text { (\%) }\end{array}$ & $\begin{array}{l}\text { S.D } \\
\text { (\%) }\end{array}$ & $\begin{array}{l}\text { Min. } \\
\text { (\%) }\end{array}$ & $\begin{array}{l}\text { Max. } \\
(\%)\end{array}$ & $\begin{array}{l}\text { C.V. } \\
(\%)\end{array}$ \\
\hline 1 & $\mathrm{PP}\left(\mathrm{g} \mathrm{cm}^{-3} \mathrm{~h}^{1}\right)$ & & & & & & & & & & & & & & & & & \\
\hline 2 & GPP g cm $\mathrm{cm}^{-3} \mathrm{~h}^{1}$ & 0.40 & 0.35 & 0.60 & 0.30 & 0.60 & 0.45 & 0.50 & 0.60 & 0.55 & 0.60 & 0.30 & 0.50 & 0.48 & 0.12 & 0.30 & 0.60 & 4.07 \\
\hline 3 & NPP $\mathrm{g} \mathrm{cm}^{-3} \mathrm{~h}^{1}$ & 0.35 & 0.45 & 0.20 & 0.25 & 0.50 & 0.40 & 0.35 & 0.20 & 0.45 & 0.40 & 0.30 & 0.50 & 0.36 & 0.11 & 0.20 & 0.50 & 3.39 \\
\hline 4 & 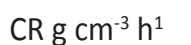 & 0.05 & 0.05 & 0.15 & 0.10 & 0.05 & 0.15 & 0.10 & 0.20 & 0.10 & 0.20 & 0.15 & 0.10 & 0.12 & 0.05 & 0.05 & 0.20 & 2.17 \\
\hline
\end{tabular}

PP: Primary productivity, GPP: Gross primary productivity, NPP: Net primary productivity, CR: Community respiration 
Table 4: Weekly observation of biological characteristics of surface water at station "B" of Goverdhan sagar Lake, Udaipur \begin{tabular}{lllllllllllllllll}
\hline No. Parameters I & II & III & IV & V & VI & VII & VIII & IX & X & XI & XII & Avg. & S.D & Min. Max. C.V.
\end{tabular}

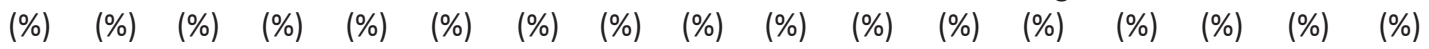

\begin{tabular}{|c|c|c|c|c|c|c|c|c|c|c|c|c|c|c|c|c|c|c|}
\hline 1 & $P P\left(g \mathrm{~cm}^{-3} h^{1}\right)$ & & & & & & & & & & & & & & & & & \\
\hline 2 & GPP g cm ${ }^{-3} h^{1}$ & 0.30 & 0.50 & 0.65 & 0.40 & 0.55 & 0.60 & 0.65 & 0.30 & 0.50 & 0.65 & 0.60 & 0.55 & 0.52 & 0.13 & 0.30 & 0.65 & 4.10 \\
\hline 3 & NPP g cm${ }^{-3} h^{1}$ & 0.25 & 0.40 & 0.35 & 0.45 & 0.25 & 0.30 & 0.50 & 0.40 & 0.55 & 0.45 & 0.55 & 0.40 & 0.40 & 0.10 & 0.25 & 0.55 & 3.91 \\
\hline 1 & $\mathrm{CR} \mathrm{g} \mathrm{cm}{ }^{-3} \mathrm{~h}^{1}$ & 0.15 & 0.15 & 0.20 & 0.15 & 0.15 & 0.10 & 0.20 & 0.25 & 0.10 & 0.15 & 0.10 & 0.15 & 0.15 & 0.05 & 0.10 & 0.25 & 3.42 \\
\hline
\end{tabular}

Table 5: Weekly observation of biological characteristics of surface water at station "C" of Goverdhan sagar Lake, Udaipur \begin{tabular}{llllllllllllllllll}
\hline No. Parameters I & II & III & IV & V & VI & VII & VIII & IX & X & XI & XII & Avg. & S.D & Min. Max. C.V.
\end{tabular}

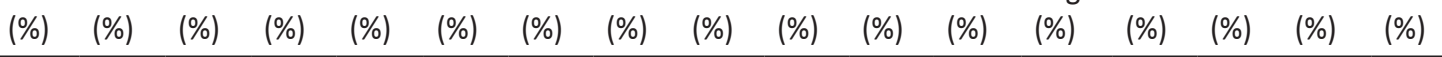

$1 \quad \mathrm{PP}\left(\mathrm{g} \mathrm{cm}^{-3} \mathrm{~h}^{1}\right)$

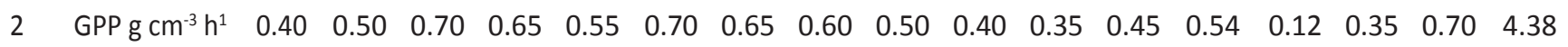

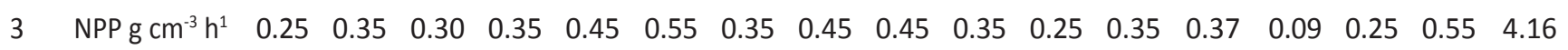

$\begin{array}{lllllllllllllllllll}4 & \mathrm{CR} \mathrm{g} \mathrm{cm}^{-3} \mathrm{~h}^{1} & 0.10 & 0.05 & 0.20 & 0.20 & 0.20 & 0.05 & 0.10 & 0.15 & 0.15 & 0.05 & 0.10 & 0.20 & 0.13 & 0.06 & 0.05 & 0.20 & 2.08\end{array}$

Mishra et al. (2016) found that the average phytoplankton count in Goverdhan Sagar was $36.71 \mathrm{No} / \mathrm{ml}$ distributed in 29 genera in the order of dominance-Chlorophyceae, Bacillariophyceae, Cyanophyceae and Desmidiaceae. Apparently, therefore, there is a significant decline in the biodiversity of phytoplankton.

The monthly average values of all three stations of overall mean phytoplankton density were more at station $C$ i.e. (150.00 Cells ml ${ }^{-1}$ ) followed by station B (148.11 Cells $\mathrm{ml}^{-1}$ ) and
Station A ( 142.50 Cells $\left.\mathrm{ml}^{-1}\right)$. The trend of dominance among the three phytoplankton groups at station A was Chlorophyceae > Cyanophyceae $>$ Bacillariophyceae $>$ Desmidiaceae. At station B the trend of dominance was Cyanophyceae $>$ Chlorophyceae $>$ Bacillariophyceae $>$ Desmidiaceae. However, at stations $C$ the relative dominance of four algal groups was Cyanophyceae> Bacillariophyceae $>$ Chlorophyceae $>$ Desmidiaceae. The overall dominance of phytoplankton is similar to the trend found at station A (Table 7).

\begin{tabular}{|c|c|c|c|c|c|c|c|c|c|c|c|}
\hline Parameters & $\begin{array}{c}\text { Air } \\
\text { temp. }\end{array}$ & $\begin{array}{l}\text { Water } \\
\text { temp. }\end{array}$ & $\mathrm{pH}$ & $\begin{array}{c}\text { Depth of } \\
\text { Vis. }\end{array}$ & $\mathrm{O}_{2}$ & $\mathrm{CO}_{2}$ & $\mathrm{HCO}_{3}$ & Alkaline & EC & TDS & $\mathrm{NO}_{3}$ \\
\hline Air temp. & 1 & & & & & & & & & & \\
\hline Water temp. & $0.9666^{* * *}$ & 1 & & & & & & & & & \\
\hline $\mathrm{pH}$ & 0.4624 & 0.5358 & 1 & & & & & & & & \\
\hline Depth of vis. & $0.9388^{* *}$ & $0.9272^{* *}$ & 0.4790 & 1 & & & & & & & \\
\hline $\mathrm{O}_{2}$ & -0.1347 & -0.0012 & 0.4150 & 0.0424 & 1 & & & & & & \\
\hline $\mathrm{CO}_{3}$ & 0.1631 & 0.1722 & -0.0728 & -0.0098 & 0.0946 & 1 & & & & & \\
\hline $\mathrm{HCO}_{3}$ & -0.5263 & $-0.5896^{*}$ & 0.0355 & $-0.5675^{*}$ & 0.1629 & -0.107 & 1 & & & & \\
\hline Alkaline & -0.4131 & -0.5111 & 0.0730 & $-0.5923^{*}$ & -0.2075 & 0.0624 & $0.7759^{*}$ & 1 & & & \\
\hline EC & $-0.8052^{* *}$ & $-0.8602^{* *}$ & -0.2926 & $-0.7345^{* *}$ & 0.0128 & -0.3613 & 0.5325 & 0.5303 & 1 & & \\
\hline TDS & $-0.8571^{* *}$ & $-0.9073^{* *}$ & -0.4204 & $-0.7761^{* *}$ & -0.0761 & -0.27 & 0.4741 & 0.4851 & $0.9589^{*}$ & 1 & \\
\hline $\mathrm{NO}_{3}$ & $-0.7331^{* *}$ & $-0.7927^{* *}$ & $-0.5554^{*}$ & $-0.8378^{* *}$ & -0.3117 & 0.2451 & 0.4277 & $0.5989^{*}$ & $0.6009^{*}$ & $0.7225^{*}$ & 1 \\
\hline $\mathrm{HPO}_{4}$ & -0.3142 & -0.5004 & $-0.5967^{*}$ & -0.3627 & -0.4939 & -0.0885 & 0.2933 & 0.3164 & 0.2823 & 0.3659 & $0.5707^{*}$ \\
\hline GPP & 0.2403 & 0.3355 & 0.4112 & 0.4851 & 0.4039 & -0.2727 & -0.4441 & $-0.6147^{*}$ & -0.0451 & -0.0668 & -0.5245 \\
\hline NPP & 0.2351 & 0.3101 & $0.6017^{*}$ & 0.4487 & 0.3960 & -0.2928 & -0.3131 & -0.3824 & 0.2148 & -0.0147 & -0.4552 \\
\hline $\mathrm{CR}$ & 0.0413 & 0.1068 & -0.4718 & 0.1433 & 0.670 & 0.0239 & -0.4066 & $-0.6986^{*}$ & -0.1987 & -0.2568 & -0.2478 \\
\hline TPP & 0.5151 & 0.6275 & 0.3856 & 0.3333 & -0.0617 & 0.3345 & -0.4243 & -0.1580 & -0.5324 & -0.2354 & -0.3658 \\
\hline
\end{tabular}




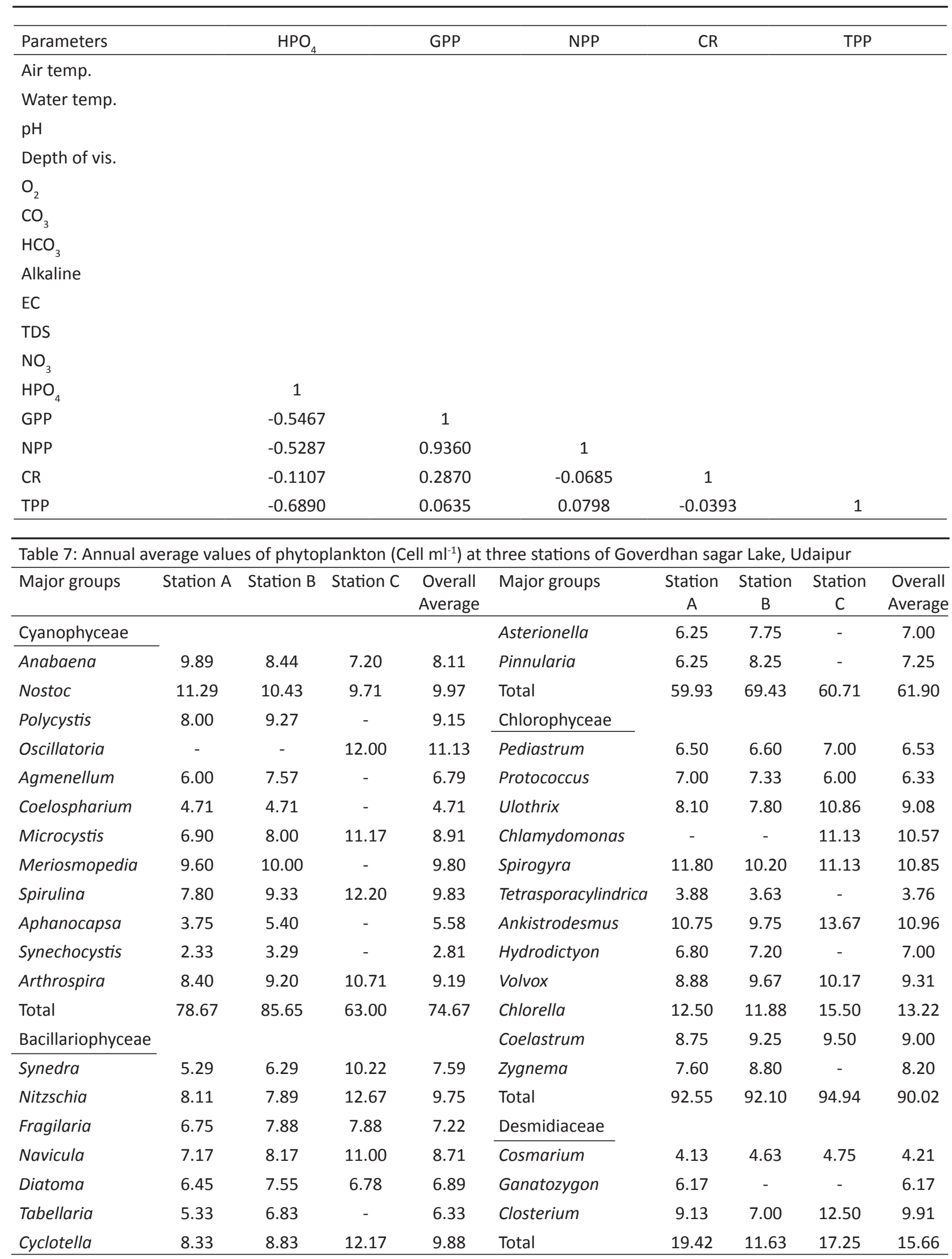




\section{Conclusion}

In any biological system biodiversity can influence both fauna and greenery. Biodiversity contributes both straight forwardly and in a roundabout way to human, for example, nourishment for good wellbeing, security, social relationship, life and opportunity of decisions and so on. Be that as it may, the misfortunes in biodiversity and change in environment benefit have unfavorably influenced the prosperity. This is contemplate clarifies that Goverdhan sagar Lake is in rich biodiversity of phytoplankton, fishes and need to preservation later on.

\section{Acknowledgment}

The authors are thankful to the Dean and Professors of the College of Fisheries, MPUAT, Udaipur for extending support, guidance and adequate laboratory facilities.

\section{References}

APHA, 2005. Standard Methods for the Examination of Water and Wastewater. 21 $1^{\text {st }}$ Edition, American Public Health Association/American Water Works Association/Water Environment Federation, Washington DC.

Bhatt Nakul, A., Singh, E., Tank, P.R., 2018. Studies on the fish and phytoplankton biodiversity with relationship to primary productivity of the Pichhola Lake, Udaipur, Rajasthan. Journal of Entomology and Zoology Studies 2018; 6(5), 1888-1893.

Bhatt, N.A., Sharma, B.K., Shwetanshumala, S.T., 2016. Lengthweight relationship and condition factor of Catla catla in Lake Pichhola, Udaipur, Rajasthan. International Journal of Fauna and Biological Studies 3(4), 19-23.

Chinnaiah, B., Madhu, V., 2010. Primary productivity of Darmasagar Lake in Adilabad, Andhra Pradesh, India. International Journal of Pharmacy and Life Sciences 1(8), 437-439.

Das, P., 1994. Conservation and Management of Cold-water Fish genetic resources. In: Coldwater Aquaculture and Fisheries. (eds.) Singh, H.R. and Lakra, W.S. Narendra Publishing House, Delhi 6, 337.

Datta, A.K., Majumdar, N., 1970. Fish fauna of Rajasthan, India (Part 7). Fish Research and Zoological Survey of India 62, 63-100.

Day, F., 1994. The fishes of India: Being a natural history of the fishes known to inhabit the seas and freshwaters of India, Burma and Ceylon. Indian Reprint, Jagmandir Book Agency, New Delhi, 1-2.

Friedland, K.D., Charles, S., Kenneth, D.F., Jason, S.L., Robert, T.L., Burton, V.S., Julie, M.R., Cynthia, H.P., Michael,
J.F., 2012. Pathways between primary production and fisheries yields of large marine ecosystem. PLoS One 7 (1), e28945.

Jain, M.K., 2000. Biology and Fisheries of Indian major carps from Siliserh reservoir, Alwar, Rajasthan. Ph.D. thesis submitted to Maharana Pratap University of Agriculture and Technology, Udaipur.

Khan, R.M., Pathan, T.D., 2016. Study of Zooplankton diversity in Triveni lake at Amravati district of Maharashtra. Journal of Global Biosciences, 5(7), 4315-4319.

Khanna, D.R., Bhutiani, R., Matta, G., Singh, V., Bhadauriya, G., 2012. Study of planktonic diversity of river Ganga from Devprayag to Roorkee, Uttarakhand (India). Environment Conservation Journal, 13(1-2), 211-217.

Kumar Dutta, T., Patra, B.C., 2013. Biodiversity and seasonal abundance of Zooplankton and its relation to physicochemical parameters of Jamunabundh, Bishnupur, India. International Journal of Scientific and Research Publications, 76.

Kumar, S., Sharma, B.K., Sharma, S.K., Upadhyay, B., 2015. Primary productivity and phytoplankton diversity in relation to fisheries potential of the Lake Udai Sagar, Udaipur. International Journal of Fauna and Biological Studies 2(5), 09-12.

Mishra, V., Sharma, S.K., Sharma, B.K., Upadhyay, B., Choubey, S., 2012. Phytoplankton, Primary Productivity and Certain Physico-Chemical Parameters of Goverdhan Sagar Lake of Udaipur, Rajasthan. Universal Journal of Environmental Research and Technology, 2(6), 569-574.

Mishra, V., Surnar, S.R., Sharma, S.K., 2016. Some limnological aspects of Goverdhan Sagar Lake of Udaipur, Rajasthan to suggest its fisheries management. International Journal of Science, Environment and Technology, 5, 2943-2948.

Rajkumar, 2005. Studies on some aspects of fish biology and fisheries potential in relation to current water quality status of Daya reservoir, Udaipur, Rajasthan. Ph.D. thesis submitted to Maharana Pratap University of Agriculture and Technology, Udaipur, Rajasthan.

Senthilkumar, R., Sivakumar, K., 2008. Studies on phytoplankton diversity in response to abiotic factors in Veeranam Lake in the Cuddalore district of Tamil Nadu. Journal of Environmental Biology 29(5), 747-752.

Talwar, P.K., Jhingran, A.G., 1991. Inland fishers of India and adjacent countries. Oxford and IBH Publishing Company, New Delhi, 1-2. 